\title{
Implementation of adidas standards for Website-Based Fabric Quality Control Test Information System
}

\author{
Mohammad Ridwan ${ }^{1}$, Hardjito S Darmojo ${ }^{2}$, Tofik Guntoro ${ }^{3}$ \\ \{mridwan@unis.ac.id ${ }^{1}$, hardjito_sd@yahoo.co.id ${ }^{2}$, tofikguntoro@gmail.com ${ }^{3}$ \} \\ Informatics Engineering Study Program, Islamic University of Sheikh Yusuf Tangerang, St. \\ Maulana Yusuf Tangerang 15118, Indonesia ${ }^{1,2,3}$
}

\begin{abstract}
PT Indo Taichen Textile Industry is a company engaged in the textile industry. Most of the products produced are fabric products with the adidas brand. Product quality control is very important to monitor the extent to which the products produced have met the set standards. So far these activities have used standard office support applications, but they are still not optimal. Therefore, this study aims to produce a website-based product quality control information system where the process starts from the adid as standard data collection in accordance with the scale specified by the adidas method, which is then used as a parameter to measure the quality of the product produced, and finally known to be feasible or whether or not the product is marketed. With this information system it will simplify and speed up the production flow so that production runs smoothly.
\end{abstract}

Keywords: Quality Control, Adidas Method, Information Systems

\section{Introduction}

The development of science and technology which is increasingly rapid, has brought many changes in all fields. This change is able to create a system for processing data quickly and accurately with a small risk of error. In the industrial world, an important factor for sustainable development is the importance of product quality, because each company will be evaluated by customers every day, especially on product quality. PT Indo Taichen Textile Industry is a company engaged in manufacturing fabrics that have been established since 1990. Most of the fabric products produced are adidas brand fabrics. Because the fabric product produced is adidas brand fabric, the testing standard uses the adidas standard method. Fabric quality control test process that aims to find out the status of the tests that have been carried out, whether the results of these tests pass or fail.

Constraints that are often encountered in the process of fabric quality control testing, have not used a system that supports, still using a simple way that is using Microsoft Excel software to analyze the quality control of fabric products. In using Microsoft Excel, there are still many weaknesses, for example, users still have difficulty in comparing standards with the results of testing, and there is still a lot of data that is often missed or lost during checking, which results in longer checking times, and higher error rates. For that we need a system to overcome these weaknesses. This is the background of this research. 
Research from Chairul Candra Purnama in 2017. The title "Designing a Web-Based Quality Control Data Monitoring System using the Codeigniter, PHPExcel and Highchart Framew ork". The research objective is to facilitate the performance of quality control for processing data. The system is made based on web using the framework codeigniter, PHPExcel and Highchart. Research methodology, system development methods using the prototype method. The advantage of this system is that the data generated can be changed in graphical form so that it will facilitate the reading and monitoring of data. The weakness of this system is that the system is only designed to change data only and in the data input process, employees are still using the old system.[1]

Research from Supriyadi in 2017. The title "Information System End Data Quality Control Process at PT Noble Batam Web Based Using PHP Programming Language". The purpose of this study is to design a data quality control system to be more efficient and fast. time and expenditure in the data input process so that with this system there is no need to use manual stationery because the system is already computerized. The advantage of this system is that it makes it easier to find data when there are claims from customers. The weakness of this system is that there is no detailed explanation of the specified standard reference.[2]

Based on the background description above, then the problem can be formulated How to build a fabric quality control information test system using the standard adidas method.

To limit the scope of discussion discussed in this report, the authors limit the problem as follows:

- The object of research is PT Indo Taichen Textile Industry in the Quality Control Laboratory.

- The system only covers the testing of fabrics on the standard adidas method in PT Indo Taichen Textile Industry with the test results obtained.

- Users of this system are Quality Control operators in the Test Laboratory section.

\section{Research Methods}

2.1. Method of Collecting Data

Observation Method, Data collection method is carried out by looking at and observing objects that involve the writer directly at PT Indo Taichen Textile Industry. Intervie w Method, Data collection method is carried out by conducting question and answer directly with the user (operator) associated with the object or problem under study in order to complete the required data.

Library Studi Method, Is a method of data collection which is done by reading books and analyzing and processing, so that it can be presented as data needed by the author. 


\subsection{System Development Modelling}

The system design modelling used in this study is UML approach. Unified Modeling Language is a language for specifying, visualizing, constructing and documenting artifacts (parts of information used or produced by software manufacturing processes, such as in business modeling and other non-software systems). UML also uses classes and operations in its basic concept, so it is more suitable for writing software in object-oriented languages such as C ++, Java, C \#, or VB.NET. Nevertheless, UML can still be used for procedural application modeling in VB or C.[7]

\subsection{Adidas Method}

Fabric quality testing methods use the standard adidas method which consists of:

Physical Test, Testing is done physically on fabric products including Dimensional \& Appearance Change in Home Laundry, Spirality, Random Tumble Pilling, Fabric Weight, Cuttable Width, Elongation \& Recovery, Bursting Strength.

Colour Fastness Tests, Tests to determine the color resistance of the fabric, including Color Fastness to Washing, Color Fastness to Perspiration, Color Fastness to Water, Color Fastness to Crocking, Phenolic Yellowing.

Fungsional Test, Tests on fabrics that have certain functions include Water Absorbency, Drying Time, Resistance to Surface Wetting.

\section{Result And Discussion Research}

3.1. System Design

Running System Analysis, Analysis of the system that runs in the PT Indo Taichen Textile Industry test quality laboratory can be seen in the flow chart as follows:

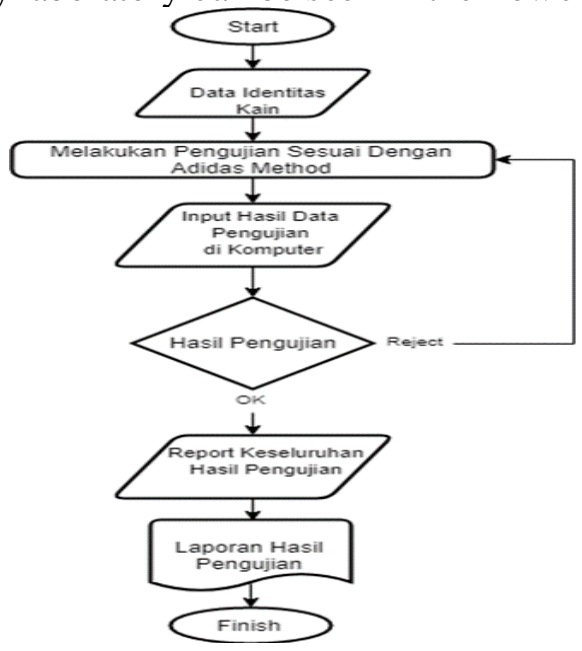

Figure 1. Current system flow chart

Problem Analysis, The data input process that is still manual using Microsoft Excel will require a longer testing and checking time and impact on the smooth production 
because they have to wait for quality results first. Operators also experienced difficulties when comparing test results with established standards (in this study using the standard adidas method). The absence of a system that makes it easy for operators to conduct testing and checking to accelerate the smooth production and compare with established standards by producing accurate fabric quality data.

Solving Solution, Designing a system that can accelerate the smooth production with accurate data in accordance with established standards with information about the latest standards because it is likely that every year will always update the standard.

\subsection{Proposed System Design}

After conducting research and analysis of the running system, the next system design proposal will be built. To analyze the proposed system, this study uses a use case diagram. For more details about the description of the system that will be proposed at PT. Indo Taichen Textile Industry can be seen from the following description.

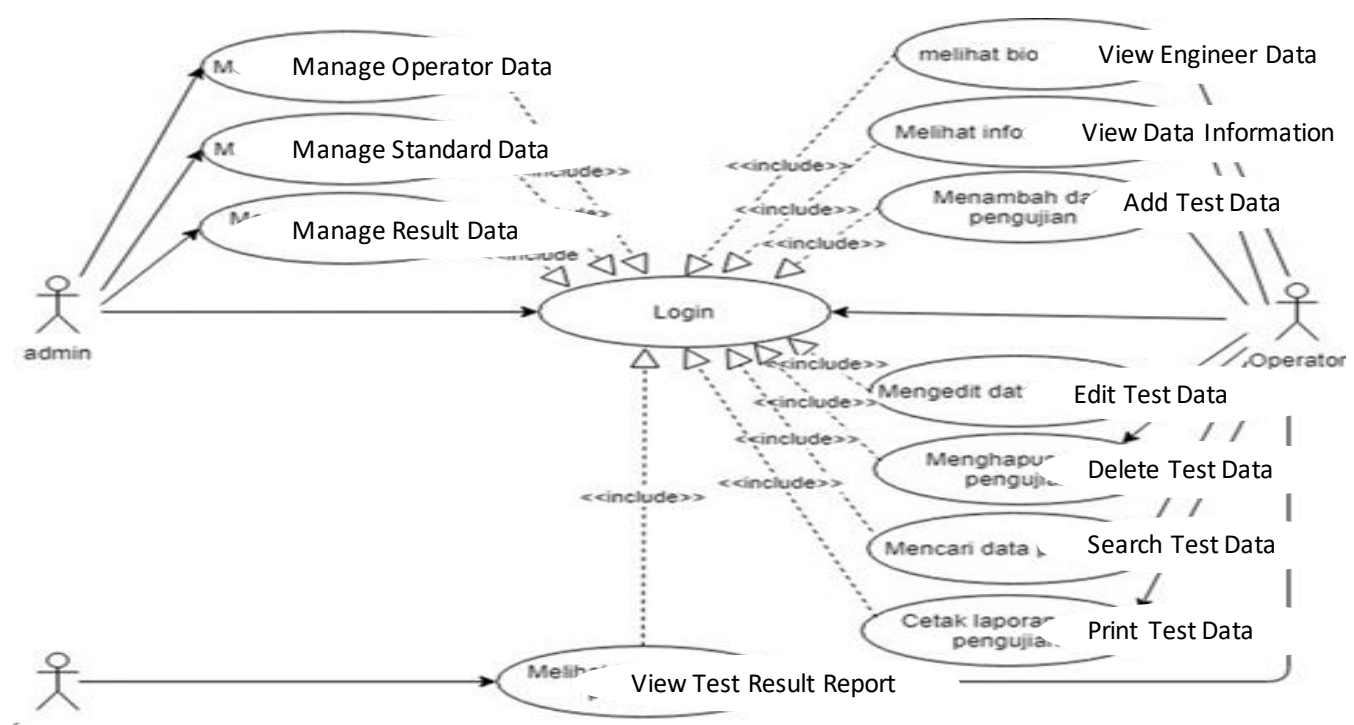

Manager

Figure 2. Use Case Proposed System Case

The picture above explains that the admin is someone who has full access rights to the quality control system application. Admin manages operator data, standard data and test result data. Operator is someone who plays an important role in the quality control system application that uses test result data. Operators can view biodata, view the latest standard information, add test result data, edit data, search data, delete data and print data reports. The manager is someone who acts as the recipient of the overall test data report. 


\subsubsection{Activity System Design Diagram}

In designing system activities, we use activity diagrams to inform the system's active flow so that goals are reached. The following picture activity diagram behavior of system users in carrying out system activities and also the system's reaction to receiving actions from users :

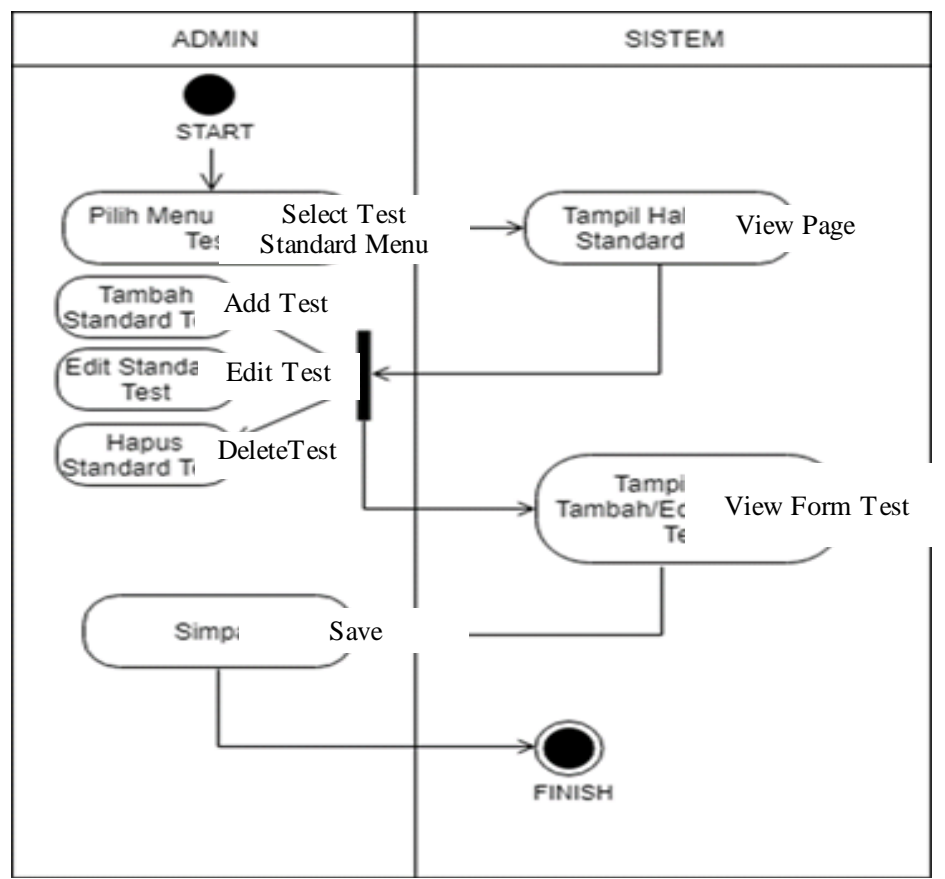

Figure 3. Activity Diagram Admin Menu Standard Test

\subsubsection{Class Design Diagram}

while in designing database systems, we use class diagrams so that the interconnection between data and also the behavior of data that will be controlled by the system. The following picture class diagram of the system in forming data connections and operations : 


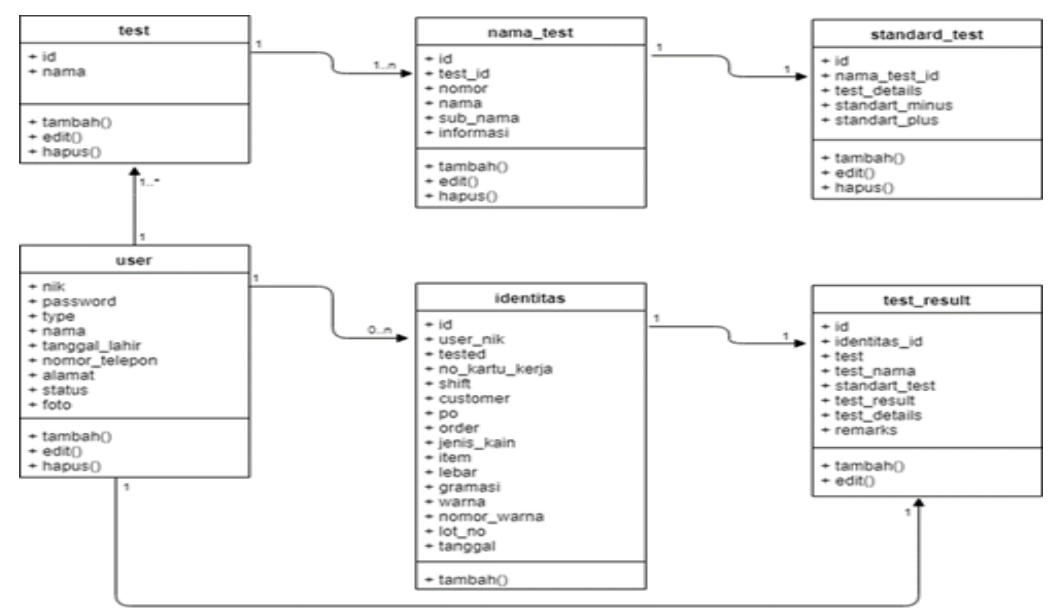

Figure 4. Class Proposed System Diagram

3.3. System Interface Result

with several designs that have been engineered, we have succeeded in making a system with several face to face as below:

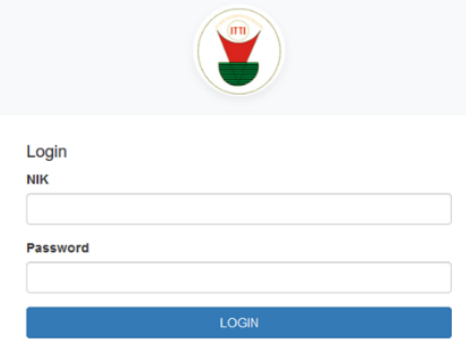

Figure 5. Login Page Display

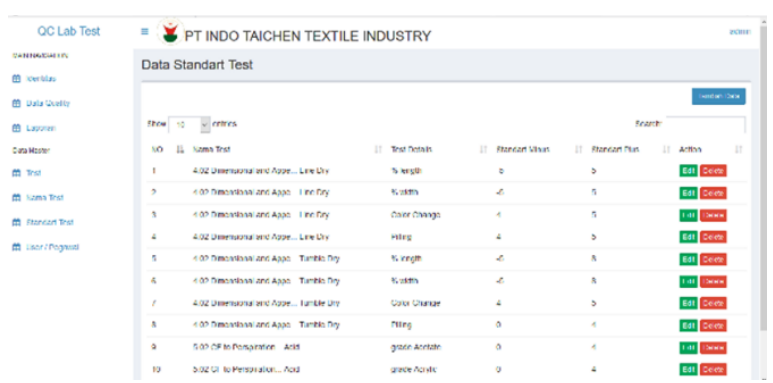

Figure 7. Standard Test Menu Page Display

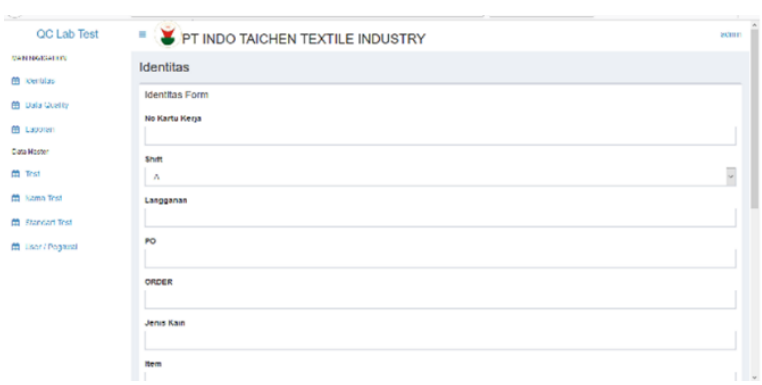

Figure 6. Admin Page Display

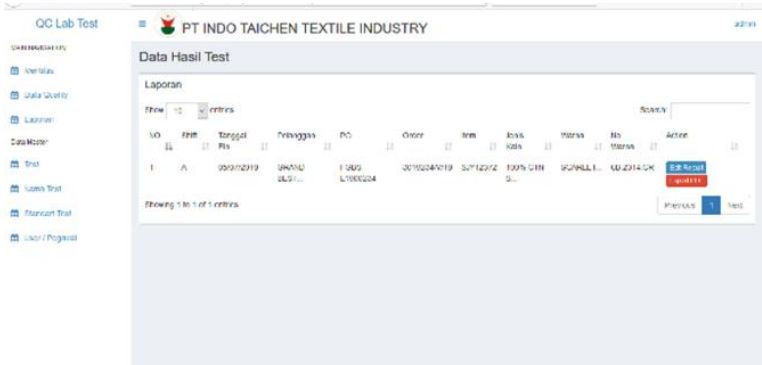

Figure 8. Display the Report Menu Page

\subsection{System Testing}

in the system testing phase, researchers involve system users who will directly interact with the system interface in the hope that the researcher can analyze the 
results of the test and will then be used as material for improvement. The following results are tested according to their respective functions :

Table 1. Fabric Identity Data Input Form

\begin{tabular}{|c|c|c|c|}
\hline Data Input & Which is expected & Observation & Conclusion \\
\hline $\begin{array}{l}\text { Fill in all input fields } \\
\text { on the identity form } \\
\text { and click the save } \\
\text { button }\end{array}$ & $\begin{array}{l}\text { The system will } \\
\text { receive and data stored } \\
\text { on the server }\end{array}$ & As expected & $\begin{array}{l}{[\mathrm{x}] \text { be accepted }} \\
{[\text { ] rejected }}\end{array}$ \\
\hline
\end{tabular}

Table 2. Test Data Input Form

\begin{tabular}{llll}
\hline Data Input & Which is expected & Observation & Conclusion \\
\hline $\begin{array}{l}\text { Fill in all input fields } \\
\text { in the test data form } \\
\text { and click the save } \\
\text { button }\end{array}$ & $\begin{array}{l}\text { The system will } \\
\text { receive and data stored } \\
\text { on the server }\end{array}$ & As expected & $\begin{array}{l}\text { [x] be accepted } \\
{[\text { ] rejected }}\end{array}$ \\
\hline
\end{tabular}

Table 3. Data Name Form Input

\begin{tabular}{llll}
\hline Data Input & Which is expected & Observation & Conclusion \\
\hline $\begin{array}{l}\text { Fill in all input fields } \\
\text { on the test name data } \\
\text { form and click the }\end{array}$ & $\begin{array}{l}\text { The system will } \\
\text { rave button }\end{array}$ & As expected & stored on the server \\
sace accepted \\
\hline
\end{tabular}

Table 4. Standard Test Data Input Form Table

\begin{tabular}{llll}
\hline Data Input & Which is expected & Observation & Conclusion \\
\hline $\begin{array}{l}\text { Fill in all input fields } \\
\text { on the standard test } \\
\text { data form and click the }\end{array}$ & $\begin{array}{l}\text { Theceive and data } \\
\text { save button }\end{array}$ & As expected & [x] be accepted \\
sared the server & & [ ] rejected \\
\hline
\end{tabular}

Table 5. User Data Input Form

\begin{tabular}{|c|c|c|c|}
\hline Data Input & Which is expected & Observation & Conclusion \\
\hline $\begin{array}{l}\text { Fill in all input fields } \\
\text { in the user data form } \\
\text { and click the save } \\
\text { button }\end{array}$ & $\begin{array}{l}\text { The system will } \\
\text { receive and data } \\
\text { stored on the server }\end{array}$ & As expected & $\begin{array}{l}{[\mathrm{x}] \text { be accepted }} \\
{[\text { ] rejected }}\end{array}$ \\
\hline
\end{tabular}




\section{Conclusion}

Based on the description of the research carried out, the following conclusions can be made:

This website-based fabric quality control information system information can help simplify and speed up the work of operators in the process of data input of fabric quality results. With the website-based fabric quality control test information system, the product w orkflow process will be faster so there is no build-up of work cards in the quality control test laboratory Make it easy in terms of fabric quality data analysis results because the presentation of fabric quality data results are neater so as to speed up decision making.

\section{Suggestion}

For the development of this research, the following suggestions can be given: In making the quality control information test system the fabric quality standard only covers the testing standards using the adidas method standard, for further development, the AATCC, ISO, ASTM and JIS method testing standards can be added to be more complete. This information system in the process of inputting fabric data into the test laboratory is still input manually, for further development barcode numbers can be made on each product so that the smooth performance of the operator will be even faster.

\section{References}

[1] C. C. Purnama, "Perancangan Sistem Monitoring Data Quality Control Berbasis Web Menggunakan Framework CodeIgniter, PHPExcel dan Highchart (Studi Kasus : PT. Pura Baru Utama)," no. 672013603, pp. 1-23, 2017.

[2] Supriyadi, "Sistem Informasi End Data Proses Quality Pada PT Noble Batam Berbasis Web Menggunakan Bahasa Pemrograman PHP," STMIK GICI Batam, 2017.

[3] R. Taufik, Sistem Informasi Manajemen. Yogyakarta: Graha Ilmu, 2013.

[4] T. Sutabri, Analisis Sistem Informasi. Yogyakarta: Andi Offset, 2012.

[5] D. Internal, Adidas Method. 2018.

[6] Maxmanroe, "Pengertian Website," 2019. [Online]. Available: https://www.maxmanroe.com/vid/teknologi/internet/pengertian-w ebsite.html. [Accessed: 09-Mar-2019].

[7] A. S. Rosa, Rekayasa Perangkat Lunak Terstruktur dan Berorientasi Objek. Bandung: Informatika, 2016. 